\title{
KEPEMIMPINAN KEPALA SEKOLAH YANG IDEAL
}

\author{
SARI MAHARANI \\ Universitas Negeri Padang \\ Email: sari.maharani2707@gmail.com
}

\begin{abstract}
This paper aims to describe the ideal leadership of the principal. ideal principal leadership has special characteristics such as a) focus on the group, b) delegates authority, c) stimulates creativity, d) encourages and motivation, e) thinks about joint participation programs, f) pays attention to human resources, g) discuss competition, $h$ ) creative and proactive, $i$ ) build character, culture and school climate, j) cooperate with the community, $k$ ) scattered leadership, l) complete vision, $m$ ) trust the teaching staff, $n$ ) responsibility, o ) exemplary, p) providing excellent service.
\end{abstract}

Keywords: leadership; headmaster.

\section{PENDAHULUAN}

Banyak factor yang menentukan keberhasilan pencapaian tujuan pendidkan di sekolah, salah satunya adalah kepemimpinan kepala sekolah. Menurut (Daryanto, 2011) kepemimpinan adalah proses mempengaruhi kegiatan-kegiatan suatu kelompok yang ada di organisasi, menuju kepada pencapaian tujuan. Sedangkan kepala sekolah merupakan seorang tenaga professional guru yang diberi tugas untuk memimpin suatu sekolah dimana diselenggarakan proses belajar mengajar atau tempat dimana terjadi interaksi antara guru yang memberi pelajaran dan murid yang menerima pelajaran. Dengan ini kepala sekolah bisa dikatakan sebagai pemimpin di satuan pendidikan yang tugasnya menjalankan manajemen satuan pendidikan.

Kepala sekolah mempunyai peranan yang sangat penting sebagai pemimpin dalam menggerakka kehidupan sekolah untuk mencapai tujuan. Kepala sekolah merupakan pemimpin pendidikan tingkat satuan pendidikan, yang harus bertanggung jawab terhadap maju mundurnya sekolah yang dipimpinnya. Pada tingkat operasional, kepala sekolah adalah orang yang berada di garis terdepan yang mengkoordinasikan upaya peningkatan-peningkatan sekolah yang bermutu.

Kepemimpinan kepala sekolah merupakan salah satu factor yang mendorong sekolah untuk mencapai tujaun secara aktif dan efisien. Oleh karena itu, dituntut keefektifan kepemimpinan kepala sekolah dalam melaksanakan tugas dan tanggung jawabnya.

(Mulyasa, 2007) kepala sekolah bertanggungjawab atas manajemen pendidikan secara mikro, yang secara langsung berkaitan dengan proses pembelajaran. Pada dasarnya pengelolaan sekolah menjadi tanggung jawab kepala sekolah dan guru. Namun, kemampuan kepala sekolah dalam memimpin sekolah sangat berpengaruh terhadap manajemen sekolah yang baik.

Setiap kepala sekolah pasti memiliki keinginan untuk membangun sekolah ideal, namun belum tentu mampu menciptakannya, dikarenakan oleh berbagai hal yang melatarbelakanginya. Ketidakmampuan kepala sekolah dalam menciptakan sekolah yang ideal terutama berkaitan dengan pemahaman, kepedulian dan komitmennya dalam menjalankan tugas kepemimpinannya. Ada kepala sekolah yang aktif dan kreatif mempelajari berbagai hal untuk merealisasikan visi dan misinya dalam menciptakan sekolah ideal, tetapi tidak sedikit yang hanya menyibukkan diri dengan urusan administrasi dan masalah keuangan yang sebenarnya bisa dilimpahkan kepada orang lain. Selain itu, permasalahan yang terjadi adalah kurangnya pengoptimalan seluruh sumber daya yang ada 
di sekolah. Salah satunya mengenai kemampuan kepemimpinan kepala sekolah.

Berdasarkan permasalahan di atas, maka penulis member artikel ini dengan judul "Kepemimpinan Kepala Sekolah Yang Ideal".

\section{KAJIAN TEORITIS}

\section{Pengertian Kepemimpinan}

(Tim Dosen AP UPI, 2009) kepemimpinan berarti kemampuan dan kesiapan yang mengajak, menuntun, menggerakkan, mengarahkan, dan kalau perlu memaksa orang atau kelompok agar mereka menerima pengaruh tersebut dan selanjutnya berbuat sesuatu yang dapat membantu tercapainya suatu tujuan tertentu yang telah ditetapkan.

Menurut (Rivai, 2014) kepemimpinan adalah suatu perilaku dengan tujuan tertentu untuk memengaruhi aktivitas para anggota kelompok untuk mencapai tujuan bersama yang dirancang untuk memberikan manfaat individu dan organisasi.

Menurut Ordway Tead dalam (Kartono,

2011) kepemimpinan adalah kegiatan mempengaruhi orang-orang agar mereka mau bekerja sama untuk mencapai tujuan yang diinginkan.

Sedangkan Menurut Stephen P. Robbins dalam (Fahmi, 2014) kepemimpinan adalah kemampuan untuk mempengaruhi suatu kelompok ke arah tercapainya tujuan.

Berdasarkan beberapa pendapat para ahli di atas dapat disimpulkan bahwa kepemimpinan adalah Kemampuan mempengaruhi, mengarahkan tingkah laku bawahan atau orang lain untuk mencapai tujuan organisasi atau kelompok.

\section{Pengertian Kepala Sekolah}

Menurut KBBI kepala sekolah dari dua kata "kepala dan sekolah". Kata kepala diartikan sebagai ketua atau pemimpin dalam suatu organisasi atau lembaga. Sedangkan sekolah adalah sebuah lembaga dimana menjadi tempat menerima dan memberi pelajaran. Dengan demikian dapat diartikan secara sederhana kepala sekolah merupakan tenaga fungsional guru yang diberi tugas untuk memimpin suatu sekolah dimana terjadi interaksi antara guru yang memberi pelajaran dan peserta didik yang menerima pelajaran.
Menurut (Mulyasa, 2007) kepala sekolah adalah motor penggerak dan penentu kebijakan sekolah, yang akan menentukan bagaimana tujuan-tujuan dalam pendidikan pada umumnya dapat direalisasikan.

Sedangkan menurut (Daryanto, 2011) kepala sekolah merupakan personel yang bertanggung jawab terhadap seluruh kegiatankegiatan sekolah, mempunyai wewenang dan tanggung jawab untuk menyelenggarakan seluruh kegiatan pendidikan dalam lingkungan sekolah yang dipimpinnya dengan dasar pancasila.

Dari berbagai definisi di atas dapat disimpulkan bahwa kepala sekolah merupakan pimpinan tertinggi lembaga pendidikan dalam lembaga pendidikan yang bertanggungjawab terhadap segala sesuatu yang berhubungan dengan kelancaran jalannya sekolah demi terwujudnya tujuan sekolah.

\section{Pengertian Kepemimpinan Kepala Sekolah}

kepemimpinan kepala sekolah merupakan kemampuan dan wewenang untuk mempengaruhi, menggerakkan dan mengarahkan tindakan serta mendorong timbulnya kemauan yang kuat dengan penuh semangat dan percaya diri para guru, staf dan siswa dalam melaksanakan tugas masingmasing demi kemajuan dan memberikan inspirasi sekolah dalam mencapai tujuan.

\section{Pentingnya Kepemimpinan Kepala Sekolah}

Menurut (Mulyasa, 2012) kepala sekolah merupakan salah satu struktur terpenting dalam organisasi kependidikan formal. kepemimpinan kepala sekolah yang baik akan memberikan dampak positif dan perubahan yang baik dalam sistem pendidikan di sekolah.

Untuk mengetahui pentingnya kepemimpinan kepala sekolah dalam instansi pendidikan, maka perlu diketahui tugas atau fungsi kepala sekolah. Jika fungsi ini berjalan dengan baik maka akan tercipta lingkungan instansi pendidikan yang kondusif, baik bagi pendidik maupun peserta didik. Fungsi-fungsi ini mencakup:

a. Kepala sekolah sebagai Educator

Sebagai educator kepala sekolah harus senantiasa berupaya meningkatkan kualitas pembelajaran yang dilakukan oleh para guru. Dalam hal ini factor pengalaman akan mempengaruhi 
profesionalisme kepala sekolah, terutama dalam mendukung terbentuknya pemahaman tenaga kependidikan terhadap pelaksanaan tugasnya.

b. Kepala sekolah sebagai Manager

Sebagai manajer kepala sekolah harus memiliki strategi yang tepat untuk memberdayakan tenaga kependidikan melalui kerja sama. Memberikan kesempatan kepada para tenaga kependidikan untuk meningatkan profesinya dan mendorong keterlibatan seluruh tenaga kependidikan dalam berbagai kegiatan yang menunjang program sekolah. Kepala sekolah harus bersikap demokratis dalam memberikan kesempatan kepada seluruh tenaga kependidikan untuk mengembangkan potensinya secara optimal.

c. Kepala sekolah sebagai Administrator

Sebagai administrator kepala sekolah memiliki hubungan yang sangat erat dengan berbagai aktivitas pengelolaan administrasi yang bersifat pencatatan, penyusunan, dan pendokumenan seluruh program sekolah.

d. Kepala sekolah sebagai Supervisor

Sebagai supervisor kepala sekolah harus mampu menyusun program yang secara khusus dapat membantu guru dalam pengerjaan tugas sehari-harinya di sekolah.

e. Kepala sekolah sebagai Leader

Sebagai leader kepala sekolah harus mampu memberikan petunjuk dan pengawasan, meningkatkan kemauan tenaga kependidikan membuka komunikasi dua arah, dan mendelegasikan tugas. Menurut (Wahjosumidjo, 1991) kepala sekolah sebagai leader harus memiliki karakter khusuS mencakup kepribadian, keahlian dasar, pengalaman, dan pengetahuan professional, serta pengetahuan administrasi dan pengawasan.

f. Kepala sekolah sebagai Inovator

Kepala sekolah harus memiliki strategi yang tepat untuk menjalin hubungan yang harmonis dengan lingkungan agar mudah dalam mendapatkan gagasan baru. Kepala sekolah sebagai inovator harus mampu mencari, menemukan, dan melaksanakan berbagai pembaharuan di sekolah.

Dari penjelasan fungsi-fungsi kepala sekolah di atas dapat diketahui bahwa kepemimpinan kepala sekolah memiliki peran penting dalam dunia pendidikan. Karena dengan adanya kepemimpinan kepala sekolah tujuan, visi, misi yang telah disepakati bersama bisa tercapai. Yaitu dengan mengarahkan civitas akademik untuk menjalankan tugasnya.

\section{PEMBAHASAN}

Menurut

(Mulyasa,

kepemimpinan kepala sekolah yang ideal memiliki ciri-ciri khusus sebagai berikut:

\section{Fokus Pada Kelompok}

Kepemimpinan kepala sekolah lebih diarahkan kepada kelompok-kelompok kerja yang memiliki tugas atau fungsi masingmasing, tidak memfokuskan kepada individu. Hal ini akan berakibat tumbuhnya kerja sama dalam kelompok. Motivasi individu akan menjadi tugas semua orang dalam kelompok, jadi kelompok kerja menjadi sumber motivasi bagi setiap anggota dalam kelompok. Karena pimpinan selalu menilai kinerja kelompok, bukan individu, maka setiap kelompok akan berusaha memacu kerja sama yang sebaikbaiknya, kalau perlu dengan menarik teman sekelompoknya yang kurang benar kerjanya.

\section{Melimpahkan Wewenang}

Seorang kepala sekolah tidak selalu harus membuat keputusan sendiri dalam segala hal. Kepala sekolah dapat menyerahkan wewenangnya kepada kelompok-kelompok yang dipercayainya di bawah pengawasannya sendiri.

\section{Merangsang Kreativitas}

Setiap upaya meningkatkan mutu kinerja, apakah itu dalam menghasilkan barang atau jasa, pada dasarnya selalu diperlukan adanya perubahan cara. Jadi, kalau menginginkan adanya mutu yang lebih baik jangan takut menghadapi perubahan, sebab tanpa perubahan tidak akan terjadi peningkatan mutu kinerja. Perubahan bisa diciptakan oleh pemimpin, tetapi tidak harus selalu berasal dari pimpinnan. Oleh karena itu, pemimpin perlu merangsang timbulnya kreativitas di kalangan orang yang dipimpinnya guna menciptakan hal-hal baru yang sekiranya akan menghasilkan kinerja yang lebih bermutu. Seorang pemimpin tidak selayaknya 
memaksakan ide-ide lama yang sudah terbukti tidak menghasilkan mutu kinerja yang diharapkan. Setiap ide baru yang dimaksudkan untuk menghasikan sesuatu yang lebih bermutu dari manapun asalnya patut disambut baik. Orang-orang dalam organisasi harus dibuat tidak takut dalam berkreasi, dan orang yang terbukti menghasilkan ide yang bagus harus diberi pengakuan dan pengahrgaan.

\section{Memberi Semangat dan Motivasi}

Seorang pimpinan pendidikan harus selalu melakukan pembaharuan, karena dengan pembaharuan akan dapat dihasilkan mutu pendiidkan yang lebih baik. Oleh karena itu, kepala sekolah harus selalu mendorong semua orang dalam lembaganya untuk berani melakukan inovasi-inovasi, baik itu menyangkut cara kerja maupun barang dan jasa yang dihasilkan. Tentu semua itu dilakukan melalui proses uji coba dan evaluasi secara ketata sebelum diterapkan dalam organisasi.

\section{Memikirkan Program Penyertaan Bersama}

Seorang kepala sekolah harus selalu mengupayakan adanya kerja sama dalam tim, kelompok, maupun unit-unit organisasi. Program-program yang dibuat mulai dari perencanaan sampai pada implementasi dan evaluasi dilaksanakan melalui kerjasama. Maksudnya adalah mengikutsertakan semua orang di lembaga pendidikan dalam berbagai kegiatan yang sesuai dengan bakat, minat dan kemampuan masing-masing. Orang adalah aset terpenting dalam lembaga dank arena itu setiap orang harus didayagunakan secara optimal bagi kepentingan pencapaian tujuan sekolah.

\section{Kreatif dan Proaktif}

Seorang kepala sekolah harus selalu bertindak kreatif dan proaktif yang bersifat preventif dan antisipatif. Kepla sekolah tidak hanya bertindak reaktif yang mulai mengambil tindakan bila sudah terjasi masalah. Kepala sekolah yang kreatif dan proaktif selalu bertindak untuk mencegah munculnya masalah dan kesulitan di masa yang akan datang. Setiap rencana dan tindakan yang dibuat sudah dipikirkan terlebih dahulu akibat dan konsekuensinya yang akan muncul, dan kemudian dipikirkan cara mengeliminasi halhak yang bersifat negative atau berusaha meminimalkannya. Dengan demikian kehidupan sekolah selalu dalam pengendalian kepala sekolah. Dalam artian semua sudah dapat diperhitungkan sebelumnya, dan bukannya memungkinkan munculnya masalahmasalah secara mengejukan dan menimbulkan kepanikan dalam organisasi sekolah. Tindakan yang reaktif biasanya sudah terlambat atau setidaknya sudah sempat menimbulkan kerugian atau akibat negatif lainnya.

\section{Memperhatikan Sumber Daya Manusia}

Sumber daya menusia merupakan hal yang penting dalam organisasi. Oleh karena itu, sumber daya manusia harus selalu mendapatkan perhatian yang besar dari pimpinan pendidikan dalam arti selalu diupayakan untuk lebih diberdayakan agar kemampuan-kemampuannya selalu meningkat dari waktu ke waktu. Dengan kemampuan yang meningkat itulah, sumber daya manusia dapat diharapkan untuk meningkatkan mutu kinerjanya. Program-program pelatihan, pendidikan, dan kegiatan yang bersifat memberdayakan SDM harus dilembagakan dalam arti selalu direncanakan dan dilaksanakan bagi setiap orang sesuai kebutuhan dan situasi.

\section{Membicarakan Persaingan}

Untuk melihat bahwa suatu sekolah itu baik atau tidak tentu perlu ada perbandingan dengan sekolah lain. Kepala sekolah dianjurkan melakukan pembandingan dengan sekolah lain, membandingkan mutu sekolahnya dengan sekolah lain yang sejenis. Kegiatan ini disebut benchmarking. Kepala sekolah harus selalu berusaha menyamai mutu sekolah lain, bahakan harus selalu senantiasa berusaha melampaui mutu sekolah lain.

\section{Membangun Karakter, budaya dan iklim sekolah}

Karakter suatu organisasi tercermin dari pola sikap dan perilaku orang-orangnya. Menurut (Gistituati, 2012) budaya sekolah adalah system nilai, norma, keyakinan atau ideology, cara berfikir, dan harapan yang dimiliki, bersama dan dipegang teguh oleh kepala sekolah, guru dan peserta didik, serta tenaga pendukung lainnya. Karakteristik tentang budaya sekolah ini yaitu sebagai berikut:

a. Budaya adalah tingkah laku yang harus ditampilkan secara terus-menerus dan bisa diamati. Jika individu di sekolah berinteraksi, mereka memiliki kegiatan 
yang biasanya dilakukan bersama, seperti upacara bendera dan uoacara peringatanlainnya.

b. Budaya memiliki norma. Tingkah laku individu di sekolah ditentukan oleh norma yang berlaku di sekolah tersebut. Dengan kata lain, sekolah memiliki standar perilaku yang dijasikan penuntun bagi individu di sekilah dalam berperilaku.

c. Budaya sekolah memiliki aturan-aturan yang harus dilaksanakan baik oleh guru maupun peserta didik.

Misalnya, dalam lembaga pendidikan perlu dikembangkan budaya yang menjunjung tinggi nilai-nilai belajar, kejujuran dan disiplin. Nilainilai ini merupakan bagian dari budaya sekolah yang harus menjadi pedoman dalam bersikap dan bertingkah laku. Meskipun demikian karakter dan budaya organisasi hanya akan tumbuh dan berkembang bila iklim sekolah itu mendukung.

Menurut (Gistituati, 2012) iklim sekolah merupakan suatu situasi atau suasanan internal organisasi sekolah yang dirasakan oleh orang0orang yang ada di sekolah. Suasana ini tercipta karena adanya hubungan atau interaksi antar individu (kepala asekolah dengan guru, kepala sekolah dengan pegawai, guru dengan pegawai, guru dengan guru, dan guru dengan peserta didik). Iklim ini menjadi cirri khas dari suatu sekolah yang membedadkannya dengan sekolah lain, yang mempengarui sikap dan tingkah laku orang-orang yang ada di dalam sekolah tersebut.

Oleh karena itu, pimpinan juga harus selalu selalu membina iklim sekolah agar kondusif bagi tumbuh dan berkembangnya karakter dan budaya sekolah.

\section{Kepemimpinan yang Tersebar}

Pimpinan kependidikan jangan berusaha memusatkan kepemimpinan pada dirinya sendiri, tetapi harus menyebarkan kepemimpinannya pada orang lain. Kepemimpinan yang dimaksud disini adalah pengambilan keputusan dan pengaruh pada orang lain. Pengambilan tentang kebijakan organisasi tetap ditangan pimpinan taas, dan lainnya bersifat operasioan atau bersifat teknis disebarkan kepada orang lain sesuai dengan kedudukan dan tugasnya.

\section{Bekerja sama dengan Masyarakat}

Kerjasama dengan masyarakat sudah menjadi bagian penting dalam mengendalikan roda perjalanan organisasi pendidikan.

Sedangkan menurut (Barlian, 2013) agar proses kepemimpinan kepala sekolah sekolah dapat memberikan hasil yang baik terhadap sekolah, ada beberapa hal yang harus dipahami dan dikuasai oleh kepala sekolah menyangkut kepemimpinan itu sendiri, yaitu:

a. Kepala sekolah harus memahami perilaku individu dan kelompok dengan mempelajari ilmu psikologi, sosiologi, dan ilmu tingkah laku.

b. Kepala sekolah harus memiliki kemampuan yang baik dalam berkomunikasi, yaitu kemampuan mengaitkan hubungan antara bahasa, pemahaman, pemikiran, dan tingkah laku. Komunikasi merupakan sarana terbaik dalam kepemimpinan. Komunikasi dua arah harus terjalin antara kepala seklah dan bawahannya agar informasi dapat tersampaikan dengan benar. Jika salah dalam menyampaikan maksud, tentunya akan menimbulkan kekeliruan dan mengakibatkan kerugian bagi sekolah.

c. Kepala sekolah harus memiliki kemampuan untuk mempengaruhi orang lain. Kemampuan memahami untuk melihat perbedaan antara dorongan, bujukan, paksaan, dan manipulasi, serta kapan tindakan-tindakan tersebut perlu dilakukan dan kapan harus dihindari.

d. Kepala sekolah harus memiliki kemampuan dalam menggunakan kewenangan yang diberikan kepadanya. Kewenangan ini memiliki hubungan dengan tanggung jawab kepala sekolah terhadap apa yang dipmpinnya.

e. Kepala sekolah harus memiliki kemampuan dalam menentukan kapan waktu yang tepat untuk menerapkan berbagai gaya kepemimpinan dan mengetahi akibat dari penerapan gaya kepemimpinan tersebut.

f. Kepala sekolah harus memiliki kesadaran diri berkenaan dengan kemampuan per orang, gaya aklamiah, kekuatan, kelemahan dan bagaimana menyeimbangkan semua hal tersebut. 
Selanjutnya menurut pendapat berbagai para ahli kepemimpinan kepala sekolah yang ideal mencakup:

\section{Visi yang Utuh}

Menurut (Mulyasa, 2012) Kepala sekolah yang sukses dalam mengembangkan kepemimpinannya memiliki dan memahami visi yang utuh tentang sekolahnya. Visi merupakan daya pandang yang komprehensif, mendalam dan jauh ke depan, meluas, serta merupakan daya piker yang abstrak, yamg memiliki kekuatan yang amat dahsyat dan dapat menerobos batas waktu, ruang dan tempat.

Visi sekolah harus menjadi atribut kepemimpinan kepala sekolah sekarang dan masa depan, karena kepala sekolah dengan visi yang dangkal dan tidak jelas akan membawa kemunduran sekolah, dan hanya akan menghasilkan sekiolah yang buruk, yang tidak disenangi masyarakat. Disinilah pentingnya kepala sekolah memiliki dan memahami visi yang utuh tentang sekolahnya, agar dapat membawa sekolahnya kea rah kemajuan dan kemandirian.

Visi sekolah juga harus secara utuh dipahami oleh seluruh warga sekolah, agr mereka menyadari, memahami, memiliki kepedulian, dan komitmen yang tinggi pada tujuan sekolah, tujuan pembelajaran, dan akuntabilitas.

Dalam mengembangkan visinya, kepala sekolah harus mampu mendayagunakan kekuatan-kekuatan yang relevan bagi kegiatan internal sekolah. Di samping itu, kepala sekolah di dalam menetapkan visinya harus berpijak pada peningkatan kualitas di masa depan.

Idealnya, visi sekolah yang diharapkan oleh pemerintah, orang tua dan masyarakat luas adalah yang sesuai dengan tuntutan zaman, kebutuhan masyrakat, serta perkembangan IPTEKS. Uuntuk kepentingan tersebut, kepala sekolah harus memiliki visi yang utuh tentang sekolahnya dan berorientasi pada masa depan sesuai tuntutan era globalisasi.

\section{Mempercayai Staf Pengajar}

Menurut (Danim, 2009) seorang kepla sekolah sangarlah penting mempercayai staf pengajar maupun wakilnya sendiri. Tanpa kepercayaan dan sikap saling menghargai antara kepala sekolah dan staf pengajar maupun dengan wkilnya, sekolah yang bersangkutan akan terancam kombinasi kinerja yang buruk dan moral yang rendah. Kondisi ini akan menyebabkan sekolah akan terjebak dalam kondisi krisis dan tidak akan mampu mendongkrak hasil belajar siswa. Untuk itu, sangat penting sekali kepercayaan antara kepala sekolah ini.

\section{Tanggung Jawab}

Menurut (Mulyasa, 2012) tanggung jawab merupakan beban yang harus dipikul dan melekat pada diri kepala sekolah. Segala tindakan yang dilakukan oleh semua staf sekolah merupakan tanggung jawab kepala sekolah. Memikul tanggung jawab adalah kewajiban seorang pemimpin dalam berbagai situasi dan kondisi. Dalam rangka membangun kepercayaan dan tanggung jawab, setiap kepala sekolah dalam melaksanakan fungsi kepemimpinannya harus mampu membersayakan tenaga kependidikan dan seluruh warga sekolah agar mau dan mampu melakukan upaya-upaya untuk mencapai tujuan sekolah.

\section{Keteladanan}

Menurut (Mulyasa, 2012) keteladanan kepala sekolah yang selalu menjadi contoh yang baik bagi bawahannya akan menjadi salah satu modal bagi terlaksananya manajemen sekolah yang efektif. Keteladanan kepala sekolah akan membuat guru dan staf pegawai segan kepadanya dan pasti mereka juga akan meniru apa yang dilakukan oleh kepala sekolah. Perilaku keteladanan ini bisa ditunjukkan dengan sifat selalu menghargai bawahan, disiplin, ramah dan lain sebagainya.

\section{Mendelegasikan Tugas dan Wewenang}

Menurut Sudarwan (Danim, 2009) kepala sekolah harus mendukung upaya pemecahan setiap permasalahan, tetapi tidak harus selalau kepala sekolah yang memecahkan permasalahan yang terjadi, tetapi kepala sekolah dapat menyerahkan tugas dan wewenang tersebut kepada wakil atau staf pengajarnya. Dengan demikian, bila masalah itu berhasil dipecahkan, staf pengajar akan memperoleh kepuasan batin dan ini sangat penting untuk merangsang motivasi dan rasa percaya diri mereka melakukan segala macam tugas dan pekerjaan serta pelbagai persoalan sendiri secara lebih baik. Dengan member 
kesempatan seluas-luasnya kepada wakil dan staf pengajar untuk mengatasi sendiri kesulitan yang timbul, kepala sekolah dalam waktu bersamaan telah mendorong dan memupuk pertumbuhan sekolah.

\section{Cekatan dan Tegas, Sekaligus Sabar}

Kepala sekolah harus mendengarkan pendapat dan pandangan dari pelbagai pihak sebelum mengambil keputusan. Setiap lembaga atau sekolah emmerlukan keputusan yang tepat dan cepat. Jasi, yang dibutuhkan adalah kepala sekolah yang sabar sekaligus tegas dalam mengambil keputusan. Karena keputusan itu nantinya berlaku untuk semua pihak, sedapat mungkin kepala sekolah harus berkonsultasi dengan sebanyak mungkin pihak untuk mendengarkan pelbagai pendapat.

Disamping itu, kepala sekolah juga harus mengetahui sepenuhnya cara mengimplementasikan atau menerapkan keputusan-keputusan yang telah ditetapkannya. Kepala sekolah harus mampu menyiapkan suatu system atau mekanisme implementasi untuk menjamin bahwa keputusan tidak sekedar dilaksanakan, tetapi benar-benar dilaksanakan sepenuhnya.

\section{Memberikan Layanan Prima}

Menurut (Mulyasa, 2012) memberikan layanan prima atau layanan terbaik merupakan salah satu upaya menumbuhkan kepercayaan peserta didik. Layanan bagi peserta didik bukan hanya dari guru, tetapi juga dari pihak administrasi. Dalam hal ini, bila terjadi hal-hal yang dapat mengurangi layanan, kepala sekolah harus segera mengambil langkahlangkah positif agar kepercayaan kembali normal. Kepuasan peserta didik sebagai pelanggan akan dapat meningkatkan gengsi sekolah tersebut sehingga akan disenangi masyarakat dan akhirnya menjadi sekolah favorit.

\section{SIMPULAN DAN SARAN}

\section{Kesimpulan}

Kepemimpinan kepala sekolah merupakan kemampuan dan wewenang untuk mempengaruhi, menggerakkan dan mengarahkan tindakan serta mendorong timbulnya kemauan yang kuat dengan penuh semangat dan percaya diri para guru, staf dan siswa dalam melaksanakan tugas masingmasing demi kemajuan dan memberikan inspirasi sekolah dalam mencapai tujuan. kepemimpinan kepala sekolah yang baik akan memberikan dampak positif dan perubahan yang baik dalam sistem pendidikan di sekolah.

Untuk menciptakan sekolah yang baik tentu kepala sekolah harus memiliki kemampuan kepemimpinan yang ideal untuk mencapai tujuan sekolah dan tujuan pendidikan. Kepemimpinan kepala sekolah yang idela ini sangat banyak sekali meliputi focus pada kelompok, melimpahkan wewenang, merangsang kreativitas, member semangat dan motivasi, memikirkan program penyertaan bersama, memperhatikan sumber daya manusia, membicarakan persainagan, kreatif dan proaktif, membangun karakter, budaya dan iklim sekolah, bekerja sama dengan masyarakat, kepemimpinan yang tersebar. Selain itu juga ada visi yang utuh, mempercayai staf pengajar, tanggung jawab, keteladanan, mendelegasikan tugas dan wewenang, cekatan dan cerdas, sabar, serta memberikan layanan prima.

\section{Saran}

Dari kesimpulan di atas, maka sarannya adalah sebagai berikut:

kepala sekolah sebagai seorang pemimpin yang merupakan ujung tombak yang bertanggung jawab terhadap maju dan mundurnya suatu sekolah hendaknya memiliki pengetahuan, keterampilan yang baik agar dapat menerapkan kepemimpinan yang ideal di sekolah.

\section{DAFTAR PUSTAKA}

Barlian, I. (2013). Manajemen Berbasis Sekolah: Menuju Sekolah Berprestasi. Jakarta: Erlangga.

Danim, S. (2009). Manajemen dan Kepemimpinan Transformasional Kepala Sekolah. Jakarta: PT Rineka Cipta.

Daryanto. (2011). Model Pembelajaran. Bandung: PT Sarana Tutorial Nurani Sejahtera.

Fahmi, I. (2014). Manajemen Kepemimpinan: Teori dan Aplikasi. Bandung: Alfabeta CV.

Gistituati, N. (2012). Manajemen Sekolah. Padang: UNP Press.

Kartono, K. (2011). Pemimpin dan 
Kepemimpinan. Jakarta: Rajawali Pers.

Mulyasa. (2007). Menjadi Kepala Sekolah Profesional. Bandung: PT Remaja Rosdakarya.

Mulyasa. (2012). Manajemen Kepemimpinan Kepala Sekolah. Jakarta: PT Bumi Aksara.

Rivai, V. (2014). Pemimpin dan Kepemimpinan dalam Organisasi.
Jakarta: Rajawali Pers.

Tim Dosen AP UPI. (2009). Manajemen Pendidikan. Bandung: Alfabeta.

Wahjosumidjo. (1991). Kepemimpinan Kepala Sekolah. Jakarta: PT Raja Gafindo Persada. 